\title{
Peran Forum Jamaah Khotmil Qur'an Di Dalam Integrasi Sosial Masyarakat Desa Sedah Kecamatan Jenangan Kabupaten Ponorogo
}

\author{
Syaiful Ikhwan \\ Institu Agama Islam Sunan Giri Ponorogo \\ syaifuliikhwan@gmail.com \\ Moh. Hazim Ahrori \\ Institut Agama Islam Sunan Giri Ponorogo \\ hazimmoh@gmail.com \\ ABSTRAK
}

Kehidupan sosial masyarakat,masyarakat saat ini sudah sangat memprihatinkan nilai-nilai dan norma-norma agama sudah mulai bergeser diterpa oleh kebudayaan-kebudayaan baru yang semakin mengikis norma-norma agama, dengan diadakanya kegiatan khotmil qur'an untuk mempertahankan nilai-nilai agama dan untuk mendekatkan diri pada Allah Swt. Penelitian di atas Khotmil Qur'an Sebagai Strategi Dakwah Di Desa Sedah Jenangan Ponorogo dengan mengambil rumusan masalah: Bagaimana pelaksanaan dan keberlangsungan jama'ah tersebut/Khotmil Qur'an Masjid Mujahidin dan Bagaimana Integrasi social yang terbentuk dalam jama'ah Khotmil Qur'an di Masjid Mujahidin Gundi Sedah Jenangan. Penelitian ini menggunakan pendekatanan conten analisis, jenis penelitian ini adalah penelitian pustaka. Teknik pengumpulan data menggunakan teknik studi dokumenter, dimana peneliti memiliki tiga tahapan pengelolaan data yaitu: reduksi data, display data, dan kesimpulan. Hasil penelitian ini adalah sebagai berikut. Pelaksanaan kegiatan Khotmil Qur'an di Desa Sedah telah berkembang sampai saat ini bahkan sampai keluar Desa Sedah dan masyarakat semakin menerima jamaah khotmil qur'an Masjid Mujahidin sebagai sarana untuk hajatan baik untuk tawasul,kirim do'a pada leluhur yang sudah meninggal,dan untuk hajatan pernikahan dan untuk hajatan aqiqoh,sepasaran bayi. Adapun pelaksanaan khotmil qur'an di Masjid,Musola dan Rumah warga masyarakat.

Kata Kunci : Khotmil Qur'an, Strategi Dakwah

\section{ABSTRACT}

The social life of society, society today is very concerned about religious values and norms, which have begun to shift in the face of new cultures that are increasingly eroding religious norms, by holding khotmil qur'an activities to maintain religious values and to draw closer to Allah swt. The research on Khotmil Qur'an as a Da'wah Strategy in Sedah Jenangan Village, Ponorogo by taking the formulation of the problem: How is the implementation and sustainability of the congregation/Khotmil Qur'an at the Mujahideen Mosque and how is the social integration formed in the Khotmil Qur'an congregation in Gundi Sedah Jenangan Mujahideen Mosque. This study uses a content analysis approach, this type of research is library research. The data collection technique used a documentary study technique, where the researcher had three stages of data management, namely: data reduction, data display, and conclusion. The results of this study are as follows. The implementation of the Khotmil Qur'an activities in Sedah Village has grown to this day even out of Sedah Village and the community is increasingly accepting of the khotmil qur'an congregation of the Mujahideen Mosque as a means for celebrations both for tawasul, sending prayers to deceased ancestors, and for wedding celebrations and for aqiqah celebrations, baby market. As for the implementation of qur'an khotmil in mosques, prayer rooms and houses of community members. 
Keywords: Khotmil Qur'an, Da'wah Strategy

\section{A. Pendahuluan}

Apabila kita teliti tentang Islam selama ini di negeri kita, ternyata kajian agama sangat sedikit dalam bidang kemasyarakatan. Dengan meluas dan mendalam serta berpanjang-panjang, orang hanya mebincangkan seluk beluk sampai ke garis yang sekecil-kecilnya tentang Rukun Islam, Rukun Iman, orang berhujah tentang fiqih dibidang ibadah, tentang kebudayaan Islam yang menyangkut kehidupan sehari-hari dalam masyarakat(Bety:1995).

Setiap masyarakat mempunyai peran penting dalam kehidupannya. Sebagai masyarakat sosial, interaksi sosial menjadi keharusan yang selalu dilakukan dalam kehidupan. Interaksi sosial sebagai media bagi masyarakat untuk saling mengenal, mengetahui dan memahami dengan masyarakat lainnya. Tentu, tujuannya adalah untuk melakukan komunikasi sosial yang saling memberikan kemanfaatan.

Kehidupan sosial masyarakat, bergerak sesuai dengan zamannya. Kondisi saat ini menunjukkan bahwa, social masyarakat sudah bergeser kepada acuh tak acuh terhadap tetangganya, mementingkan kepentingan pribadinya, sedikit yang mempunyai rasa kasihan dan simpati sama orang lain yang lebih rendah darinya, tolong menolong sesama masyarakat sudah sedikit berkurang, seiring dengan kehidupan yang penuh dengan kesenangan dan mempunyai tujuan untuk tujuan hidupnya sendiri, terutama di perkotaan.

Di perkampungan, budaya perkotaan sudah menjadi bagian penting dalam kehidupan masyarakat kampung atau perdesaan. Gaya hidup dan sosial ke-masyarakatan perdesaan sudah mengalami berbagai pergeseran yang mengarah kepada dinamika kehidupan masyarakat perkotaan dan hampir tidak ada bedanya. Perumahan sudah mulai merambah daerah perdesaan, dengan membawa kultur kota yang notabene adalah hidup secara sendiri-sendiri sekali pun di sekelilingnya banyak tetangganya, hidup secara mandiri dan tidak membutuhkan orang lain, 
sekalipun masih banyak yang membutuhkan di sekitarnya, dan berbagai pola kehidupan yang sudah bergeser kepada paradigma pragmatisme masyarakat.

Strategi dakwah mempunyai peran dan fungsi penting dalam meningkatkan kualitas kehidupan masyarakat. Dakwah Islam sebagai wujud menyeru dan membawa umat manusia ke jalan Allah. Upaya mewujudkan Islam dalam kehidupan manusia dilakukan melalui dakwah dengan cara mengajak kepada kebaikan, mencegah kemungkaran, dan mengajak untuk beriman demi terwujudnya umat yang sebaik baiknya.

Menyeru manusia kepada Allah s.w.t. (al-Dakwah ila Allah) adalah kewajiban setiap Muslim dan Muslimat disetiap masa. Terutamanya di zaman kita ini, ia lebih wajib kerana umat Islam pada hari ini terdedah kepada serangan jahat musuh-musuh Allah s.w.t yang bertujuan mencabut teras dakwah Islam dari jiwa umat Islam. Menyeru manusia kepada Allah s.w.t adalah satu kemuliaan yang besar kepada pendukung dakwah. Menyeru dan mengajak manusia kepada Allah s.w.t dan kepada jalan yang benar, adalah sebaik-baik urusan dan amat perlu diketengahkan, terutama di zaman ini yang berkecamuk dengan pelbagai kefahaman dan ideologi, kecenderungan semasa yang menyesatkan dan menyelewengkan. Oleh karena itu, dibutuhkan sebuah penyegaran dan penguatan bagi masyarakat dalam mengenal ${ }^{\prime} \cdot$ sendiri dan masyarakatnya. Lewat sebuah kegiatan manaqib ini, akan timbul atau terjaganya nilai kerukunan atau menyambung tali silturahi.

Khotmil Qur'an itu sendiri adalah sebagai sarana mendekatkan diri kepada sang kholiq dan sebagai sarana tawassul kepada junjungan nabi besar Muhammad Saw, Ambuya' shohabat dan auliya' yang merupakan bentuk kepedulian sesama makhluk yaitu kepada yang telah meninggal, dengan tujuan agar saudaranya atau kerabatnya dapat hidup dengan tenang di alamnya dan mendapat berkah dari Allah Swt. Dalam hal ini, diyakini bahwa pelaksanaan 
Khotmil Qur'an sebagai sarana untuk mendoakan. dan bersedekah tidak lain bertujuan untuk mendoakan orang yang sudah meninggal dan agar dipermudah jalanya menuju ke Surga dan diampuni segala dosanya. Karena sesungguhnya orang yang bersedekah dengan niat pahalanya ditujukan kepada keluarga yang telah meninggal dapat diterima oleh Allah Swt.

Kegiatan membaca Al-Qur'an merupakan kegiatan yang menjadi rutinitas masyarakat Desa Sedah . Kegiatan ini berdiri sejak tahun 2007 yang terus berjalan sampai saat ini, dengan adanya kegiatan tersebut telah terbukti bahwa kondisi masyarakat Desa Sedah menjadi lebih baik. Dengan adanya kegiatan tersebut mereka juga meyakini bahwa kegiatan Khotmil Qur'an merupakan cara untuk mendekatkan diri kepada Allah Swt, dan sebagai perantara terkabulnya doa yang ditujukan kepada keluarga-keluarga yang telah meninggal.

Adanya kegiatan Khootmil Qur'an ini ternyata diterima dengan baik oleh warga Sedah. Awalnya kegiatan Khootmil Qur'an ini hanya berjumlah 30 orang kemudian seiring waktu dan dilaksanakan secara istiqomah. Setelah barjalan beberapa tahun anggota jama'ah semakin bertambah. Tepatnya pada tahun berikutnya masyarakat desa Sedah semakin menerima kegiatan Khotmil Qur'an terbukti dari beberapa kegiatan tasyakuran, selamatan, ijaban, mereka selalu mengadakan Khotmil Qur'an dalam perjuanganya pengurus Khotmil Qur'an selalu mengedepankan kepentingan masyarakat umum untuk membantu mereka dalam mengadakan hajatan. Salah satu strategi dakwah yang digunakan di jama'ah Khotmil Qur'an masjid Mujahidin Dimana Khotmil Qur'an ini bisa menjadi strategi dakwah yang cukup signifikan dalam menyampaikan nilai-nilai dakwah dan ajaran Islam..

\section{B. Metode Penelitian}

Dalam penelitian ini digunakan pendekatan kualitatif. Penelitian kualitatif perhatian lebih banyak ditujukan pada pembentukan teori substantif berdasarkan dari konsep-konsep yang 
timbul dari data empiris. Dalam penelitian kualitatif, peneliti merasa "tidak mengenal apa yang tidak diketahuinya", sehingga desain penelitian yang dikembangkan selalu merupakan kemungkinan yang terbuka akan berbagai perubahan yang diperlukan dan lentur terhadap kondisi yang ada di lapangan pengamatannya(Margono:1997). Penelitian kualitatif menggunakan metode penalaran induktif dan sangat percaya bahwa terdapat banyak perspektif yang akan dapat diungkapkan. Penelitian kualitatif berfokus pada fenomena sosial dan pada pemberian suara pada perasaan dan persepsi dari partisipan di bawah studi. Hal ini didasarkan pada kepercayaan bahwa pengetahuan dihasilkan dari setting sosial dan bahwa pemahaman pengetahuan sosial adalah suatu proses ilmiah yang sah (legitimate) (Emzir :2011).

Sedangkan jenis penelitian ini adalah studi kasus, yang mana peneliti mencoba untuk mencermati individu atau sebuah unit secara mendalam. Peneliti mencoba menemukan semua variabel penting yang melatarbelakangi timbulnya serta perkembangan variabel tersebut. Di dalam studi kasus akan dilakukan penggalian data secara mendalam dan menganalisis intensif faktor-faktor yang terlibat didalamnya (Arikunto:2000).

\section{Hasil Pembahasan}

Separuh hasil penelitian Khotmil Qur'an yang dilakukan di desa Sedah, penulis dapat mengetahui latar belakang adanya kegiatan Khotmil Qur'an di desa tersebut, bahwasanya kegiatan tersebut berasal dari inisiatif seorang kiyai yang pernah menuntut ilmu agama di Pondok Pesantren Hudatul Muna Njenes Ponorogo dan melaksanakan kegiatan Khotmil Qur'an. Teman-teman yang lainnya secara rutin, sampai suatu ketika kegiatan Khotmil Qur'an berlangsung. Kemudian kegiatan tersebut dilestarikan di desa Sedah untuk diamalkan bersamasama warga setempat. 
Dari penjelasan pada bab dua bahwa Khotmil Qur'an adalah riwayat hidup yang berhubungan dengan seorang tokoh ulama, masyarakat yang menjadi suri tauladan, baik mengenai silsilah, akhlaq, keramahan, dan sebagainya. Berdasarkan penjelasan di atas, hal ini dimanfaatkan oleh pendiri Khotmil Qur'an sebagai sarana untuk berdakwah dalam aspek kegiatan beribadah yang melalui kisah-kisah tauladan, serta tentang karamah-karamah yang telah diperoleh oleh para ulamak-ulamak terdahulu.

Dengan kegiatan tersebut diharapkan mampu menumbuhkan kesadaran warga setempat untuk selalu mendekatkan diri kepada Allah dengan berusaha tetap menjalankan perintahperintah-Nya dan menjauhi larangan-larangan-Nya. Adapun tujuan Khotmil Qur'an sendiri diantaranya untuk mendekatkan diri kepada Allah Swt melalui tawwasul terhadap para Nabi dan para kekasih Allah Swt, mendapatkan keberkahan para Auliya' serta untuk memuliakan dan mencintai dzurriyah Rasulullah Saw, ahlul bait atau keluarga Rasulullah Saw sehingga tetap terpelihara kesuciannya.

Berdasarkan tujuan tersebut, dengan keyakinan bahwa melakukan Khotmil Qur'an dapat mendapatkan keberkahan tersendiri, baik keberkahan itu dirasakan oleh keluarga-keluarga yang telah meninggal maupun sesama manusia yang masih hidup serta adanya tanggapan dan penerimaan yang baik oleh warga Mangunsuman.

Kegiatan Khotmil Qur'an merupakan kegiatan dalam rangka memohon kepada Allah Swt dengan cara bertawasul melalui kekasih-Nya.

Hal ini bertujuan agar kita selalu bertawassul kepada para kekasih Allah Swt sebagai perantara untuk mendekatkan diri kita kepada Allah Swt. Disamping itu juga bahwa majlis Khotmil Qur'an adalah suatu ibadah tambahan yang dapat menghibur kepada jama'ah secara batiniah, dan merupakan suatu sarana pendidikan spiritual dengan berjama'ah yang pada 
akhirnya membawa efek positif untuk selalu melatih meningkatkan kualitas ibadah baik secara individu, keluarga, maupun masyarakat.

Dari penjelasan bab tiga, dikatakan bahwa tradisi membaca Khotmil Qur'an tersebut, biasannya dilakukan oleh masyarakat yang berfaham ahlus sunnahwal jama'ah. Hal ini juga dapat digambarkan bahwasanya secara umum masyarakat desa Sedah banyak yang berfaham ahlus sunnahwal jama'ah, dan tentunya mereka sangat mendukung dengan adanya kegiatan tersebut. Sedangkan pelaksanaan kegiatan Khotmil Qur'an di desa Sedah dapat dikatakan berjalan dengan baik.

Secara umum setiap kegiatan-kegitan resmi selalu membutuhkan susunan acara yang dimulai dari pembawa acara (MC), sambutan dari ketua panitia, shohibul bait dan sebagainya sehingga acara yang dilaksanakan akan tertata dengan baik. Namun sebaliknya, dalam kegiatan Khotmil Qur'an secara kondisional tidak terdapat susunan acara sebagaimana di atas, kegiatan ini sepenuhnya dipimpin oleh bapak Syaiful Ikhwan selaku ketua kegiatan tersebut, sehingga kegiatan tersebut berbeda dengan kegiatan-kegiatan lainnya. Perbedaan itu bukan merupakan suatu alasan kegiatan tersebut tidak berjalan dengan baik, bahkan ini merupakan bentuk perhatian terhadap shohibul bait karena tidak semua jama'ah yang rumahnya mendapat gilirin termasuk orang terpandang, sehingga mereka enggan untuk berbicara di depan para jama'ah lain sehingga seluruhnya diserahkan kepada imam Khotmil Qur’an.

Dari penjelasan bab dua, dikatakan bahwa acara Khotmil Qur'an dibuka dengan membaca Al-Fatihah yang pahalanya ditujukan kepada para Nabi, Syuhada, Shalihin Auliya' dan lain-lainnya di bawah pimpinan seorang imam dan diteruskan pembacaan doa. Setelah itu barulah dimulai pembacaan Khotmil Qur'an 
Pelaksanaan Khotmil Qur'an di desa Sedah terdapat persamaan sebagaimana tercantum dalam bab dua yakni dilaksanakan dengan pembukaan (muqodimmah) oleh imam kegiatan terlebih dahulu sebagai perwakilan dari tuan rumah, kemudian diteruskan dengan membaca tawassul dan ketika sampai pada bacaan surat al-Na<s barulah dimulai pembacaan Khotmil Qur'an yang dibaca oleh seseorang yang merupakan pilihan imam kegiatan tersebut. Kegiatan tersebut berlangsung dengan para jama'ah saling memperdengarkan bacaan Al-Qur'an selesai.

Pengaruh Khotmil Qur'an terhadap kondisi social masyarakat sekitar Masjid Mujahidin memberikan dampak yang positif bagi jamaah. Dari hasil penelitian, penulis dapat menyimpulkan bahwa adanya kegiatan Khotmil Qur'an di desa Sedah ternyata memberikan dampak yang positif bagi sebagian besar jama'ah, terbukti berdasarkan data-data yang peneliti peroleh menunjukkan bahwa para jama'ah mampu lebih baik dalam mendekatkan diri kepada Allah Swt. Dan hal ini merupakan keberhasilan yang tidak dimiliki oleh semua orang.

Berdasarkan penjelasan pada bab dua bahwasanya seseorang yang telah memperoleh kecerdasan spiritual karena puncak dari kecerdasan spiritual adalah diri dapat merasakan dekat, cinta ketuhanan, yaitu kecintaan diri terhadap Allah dan kecintaan Allah terhadap diri ini, dan merasa berjumpa kepada Allah.

Berhubungan dengan perasaan dekat, dan cinta terhadap Tuhannya seseorang akan dapat mengetahui hakikat di balik ayat-ayat yang tersurat maupun tersirat dari ayat-ayat qauliyyah (AlQuran) maupun ayat-ayat kauniyyah (yang terhampar pada alam semesta raya dan kehidupan sehari-hari). Hal ini telah dimiliki oleh para jama'ah kegiatan Khotmil Qur'an, bahkan selain hal tersebut para jama'ah Khotmil Qur'an dapat mengetahui dibalik semua kebaikan atau karamah para auliya' Allah Swt mampu memberikan keberkahan yang luar biasa dalam kehidupannya. Keberkahan inilah yang merupakan suatu harapan khusus bagi para jama'ah Khotmil Qur'an 
dalam mengikuti kegiatan tersebut. Dan hal ini ternyata sudah banyak mereka rasakan selama mengikuti kegiatan tersebut, diantaranya mereka mampu melaksanakan ibadah dengan lebih baik, segala urusan duniawinya dapat tercukupi dengan baik, bahkan ketika mereka mendapatkan suatu permasalahan mampu menyelesaikannya dengan bijaksana dan tidak merugikan diri sendiri maupun orang lain.

Beribadah yang sempurna merupakan wujud ketekunan seseorang dalam berusaha untuk menuju kebaikan yang lebih baik. Hal ini tentunya akan lebih sempurna jika dalam melakukan ibadah selalu menumbuhkan rasa cinta terhadap apa yang menjadi tujuannya. Misalnya seseorang melakukan ibadah dengan tujuan mengharap ridho Allah Swt, maka jika harapan yang dinginkan tersebut dapat terpenuhi dengan baik ia harus selalu berusaha untuk menumbuhkan rasa cintanya kepad Allah Swt.

Dalam mewujudkan rasa cinta kepada Allah Swt ternyata dapat dilakukan dengan berbagai cara, diantaranya mencintai apa yang telah diciptakan Allah Swt, misalnya dengan cara mencintai para utusan-utusan-Nya atau para auliya' dan kekasih-kekasih-Nya. Hal ini sebagaimana yang dilakukan oleh para jama'ah Khotmil Qur'an warga desa Sedah, mereka mewujudkan rasa cintanya kepada Allah dengan cara sima'an Al-Qur'an mereka selalu berusaha untuk lebih baik dalam menjalani kehidupan sehari-hari, kerena dengan mencintai Nabi, Sahabat, Auliya', Para Masyayih mereka dapat mencontoh kebaikan-kebaikannya yang selalu menuntun dalam mendekatkan diri dan megharapkan ridho dari Allah Swt atas segala ibadah yang dikakukan.

Di sisi lain dalam mengharapkan keridhoan Allah Swt maka seseorang diharuskan memiliki sifat Shiddiq (jujur/benar), yaitu hadirnya suatu kekuatan yang membuat terlepasnya diri dari sikap dusta atau tidak jujur terhadap Tuhannya, dirinya sendiri, maupun orang lain. Hal 
ini merupakan salah satu hal utama yang harus dimiliki para jama'ah dalam mengikuti kegiatan Khotmil Qur'an dikarenakan tanpa adanya kejujuran yang menyatakan bahwa kegiatan Khotmil Qur'an itu merupakan kegiatan yang benar dan berdampak positif maka mereka tidak akan mendapatkan apa yang menjadi tujuan mereka.

Dalam menjalani kehidupan sehari-hari tentunya setiap manusia tidak akan lepas dari ujian atau cobaan. Dengan kekuatan iman yang menjadi dasar ibadah seseorang tentunya tidak akan menjadikan suatu penghalang untuk mengeluh setiap mendapatkan kesusahan, bahkan ini menjadikan seseorang akan lebih mengetahui tentang sejauh mana kita mampu menyikapi setiap masalah dalam menyelesaikannya.

Berdasarkan penjelasan bab dua bahwasanya orang yang memiliki sifat amanah tentu dapat menghadirkan suatu kekuatan yang dengannya ia mampu memelihara kemantapan spiritualnya, tidak berkeluh kesah jika ditimpa kesusahan, sebagaimana yang dikatakan oleh jama'ah Khotmil Qur'an desa Sedah bahwa ujian dalam menjalani hidup itu sudah pasti ada dan itu merupakan sunatullah namun dengan adanya ujian tersebut mereka meyakini bahwa tidak seluruhnya ujian yang diberikan kepada kita iru merupakan bentuk kebencian Allah kepada kita melainkan suatu tantangan yang bilamana kita mampu melaluinya kita akan diankat deraja kita menjadi lebih baik, tentunya segala usaha yang kita lakukan dengan maksimal kita kembalikan kepada Allah Swt, sedangkan hasilnya hanya Allah yang mengetahui.

Dari keterangan di atas dapat disimpulkan bahwa segala ujian yang Allah berikan kepada kita, jika kita terima dengan kesabaran dan tanapa keluhan pasti Allah akan memberikan hal yang lebih baik kepada kita. Karena ini merupakan tolok ukur kekuatan manusia dalam melaksanakan perintah Allah Swt dan menjauhi segala larangan-larangan-Nya. 
Seseorang yang sehat ruhaninya, senantiasa mendengar dan mentaati ajakan dari titahtitah nuraninya. Segala kegiatan yang mungkin dapat mendatangkan kerugian bagi diri sendiri maupun orang lain akan berkurang jika memperhatikan keinginan nuraninya, karena pada dasarnya setiap orang yang melakukan kesalahan akan bertolak dengan nuraninya, yang mana nuraninya akan menolak untuk melakukan kesalahan tersebut.

Kesadaran yang tinggi telah mengenal seseorang yang memiliki keceerdasan spiritual. Dia akan mampu mengendalikan dirinya, misalnya mengendalikan emosi dan dorongandorongan lainnya. Dengan mengenal dirinya, maka dia juga mengenal orang lain, mampu membaca maksud dan keinginan orang lain. Kesadaran lingkiungan tinggi mendakup kepedulian terhadap sesama. Sebagaimana yang dilakukan oleh para jama'ah Khotmil Qur'an Sedah bahwasanya mereka mampu meningkatkan kesadaran dirinya dalam hidup bermasyarakat, hal ini diwujudkan dengan cara partisipasi mereka terhadap kegiatan-kegiatan di masyarakat terutama dalam kegiatan Khotmil Qur'an tersebut. Selain itu mereka juga memiliki kesadaran yang tinggi bagi diri sendiri, dengan selalu berusaha memaksakan diri untuk tetap menjalankan perintah Allah Swt sebagiamana yang telah disyari’atkan agama Islam.

\section{Kesimpulan}

Pelaksanaan kegiatan Khotmil Qur'an dimulai dari pembukaan, setelah itu dimulai tawasul, dilanjutkan pembacaan sima'an Al-Qur'an, serta pembacaan Dzikrul ghofilin dan dilanjutkan Do'a dan solawat. Dan telah berkembang sampai saat ini bahkan sampai keluar Desa Sedah dan masyarakat semakin menerima jamaah khotmil qur'an Masjid Mujahidin sebagai sarana untuk hajatan baik untuk tawasul,kirim do'a pada leluhur yang sudah meninggal,dan untuk hajatan pernikahan dan untuk hajatan aqiqoh,sepasaran bayi. Adapun pelaksanaan khotmil qur'an di Masjid,Musola dan Rumah warga masyarakat. 


\section{Daftar Pustaka}

Abd. Wahab dan Umiarso, Kepemimpinan Pendidikan Dan Kecerdasan Spiritual, Jogjakarta: Ar-Ruzz Media, 2011.

Abid Bisri Musthofa dkk, Terjemah Muwaththa'Al-Imam Malik r.a, Semarang, CV. Asy Syifa',1992.

Adz-Dzakiey, Hamdani Bakran. Psikologi Kenabian; Prophetic Psychology, Yogyakarta: Fajar Media Press, 2012.

Al-Aziz, Moh. Syaifulloh. Terjemah Mana<qib (Kisah Kehidupan) Syaikh Abdul Qadir AlJailani, Surabaya: Terbit Terang, 2000.

Al-Hasyimiy,Muhammad Ma'shum Zainy. Ternyata...! NU Tidak Bid'ah, Jombang: Darul Hikmah Jombang, 2009.

Al-Kaaf, Habib Abdullah Zakiy. Ajaran Tasawuf Seikh Abdul Qadir Al- Jailani, Bandung: CV.Pustaka Setia, 2003.

Ariesto Hadi Sutopo dan Adrianus Ariel, Terampil Mengolah Data Kualitatif dengan Nvivo, Jakarta : Kencana, 2010.

Arikunto, Suharsimi. Manajemen Penelitian, Jakarta: Renika Cipta, 2000.

At-Tadafi, Muhammad bin Yahya. Mahkota Para Aulia, Jakarta: Prenada, 2005.

Basrowi dan Suwandi, Memahami Penelitian Kualitatif,Jakarta : Rineka Cipta, 2008.

Burhanudin Dzikry \& Sibawaihi, Propethic Intellingenci; Kecerdasan Kenabian Mengembangkan Potensi Robbani Melalui Peningkatan Kesehatan Ruhani, Yogyakarta: Al-Manar, 2013.

Creswell, John W. Research Design Pendekatan Kualitatif, Kuantitatif, dan Mixed, terj. Achmad Fawaid, Yogyakarta: Pustaka Pelajar, 2013.

Danah Zohar dan Ian Marshall, SQ Kecerdasan Spiritual, Bandung: PT.Mizan Pustaka, 2007.

Danah Zohar dan Lan Marshal, SQ Kecerdasan Spiritual, Bandung: PT. Mizan Pustaka, 2001.

DEPDIKBUT, Kamus BesarBahasa Indonesia 2, Jakarta: Balai Pustaka, 1995.

Emzir, Analisis Data: Metodologi Penelitian Kualitatif, Jakarta: Rajawali Pers, 2011.

Iskandar, Psikologi Pendidikan, Jakarta Selatan: Referensi, 2012.

M. Djunaidi Ghony \& Fauzan Almanshur, Metode Penelitian Kualitatif, Yogyakarta: Ar-Ruzz Media, 2012.

Ma'arif, Syamsul. Revitalisme Pendidikan Islam, Yogyakarta: Graha Ilmu, 2007.

Margono, S. Metodologi Penelitian Pendidikan, Jakarta: Rineka Cipta, 1997.

Margono, S. Metodologi Penelitian Pendidikan, Jakarta: Rineka Cipta, 2003.

Moleong, Lexy J. Metodologi Penelitian Kualitatif, Bandung: PT Remaja Rosdakarya, 2013.

Monty P. Satiadarma \& Fidelis E. Waruwu, Mendidik Kecerdasan, Jakarta: Pustaka Populer Obor, 2003.

Nur, Nurhidayat M. Kerancuan Memahami Islam, Yogyakarta: Pustaka Pesantren, 2012.

Ridwan, Agus Abdul Qadir. Gerbang Pesantren Pengantar Memamahi Ajaran Ahlusunnah Wal jamaah, Kediri: Bidang Penelitian dan Pengembangan LIM, 2009.

Sarosa, Samiaji. Penelitian Kualitatif: Dasar-dasar, Jakarta: PT Indeks, 2012.

Scharf, Betty R. Kajian Sosiologi Agama. Ter. Drs. Mahmun Husein, Yogyakarta: PT. Tiara Wacana Yogya, 1995.

Soeleiman Fadeli dan Mohammad Subhan, Antologi NU, Sejarah Istilah Amaliah Uswah, Surabaya: Khalista, 2007. 
Tim Penyusun, Buku Pedoman Penulisan Skripsi Kuantitatif, Kualitatif, Library, PTK, Ponorogo: Jurusan Tarbiyah Sekolah Tinggi Agama Islam Negeri STAIN) Ponorogo, 2015.

Zuhri, Achmad Muhibbin. Pemikiran K.H M. Hasyim Asy'ari Tentang Ahl al-Sunnah wa alJaa'ah, Surabaya: Khalista, 2010. 